\title{
Migration, Xenophobia and New Racism in Post-Apartheid South Africa
}

\author{
Carol Adjai $^{1} \&$ Gabriella Lazaridis ${ }^{2}$ \\ ${ }^{1}$ Department of Politics and International Relations, University of Leicester, Leicester, England \\ ${ }^{2}$ Department of Politics and International Relations, University of Leicester, Leicester, England \\ Correspondence: Gabriella Lazaridis, Department of Politics and International Relations, University of Leicester, \\ Unversity Road, Leicester, LE1 7RH, England. E-mail: g136@le.ac.uk
}

Received: January 24, 2013 Accepted: February 19, 2013 Available online: March 19, 2013

doi:10.11114/ijsss.v1i1.102 URL: http://dx.doi.org/10.11114/ijsss.v1i1.102

\begin{abstract}
Post-apartheid South Africa was built on a culture of inclusiveness, tolerance and human rights, embodied in its 1996 Constitution. However, as this paper shows, South African citizens exhibit high levels of xenophobia towards fellow African citizens, subjecting them to different forms of prejudice and discrimination. The paper argues that the racialization of African migrants- the other- and xenophobic sentiment are about the politics of access; a struggle for political and socio-economic resources.
\end{abstract}

Keywords: xenophobia, new racism, discrimination, South Africa, immigration, migration

\section{Introduction}

An increasing number of scholars have tried to analyse contemporary racism and to develop a set of hypotheses that would account for the racialized social relations in various national and local settings, at a time of social and cultural change. Compared to the plethora of studies covering immigration in several European countries (see for example Togral, 2011), one finds relatively less acknowledgement of racism in the literature on migration in the new South Africa (Bloch, 2010; Crush, 2003; Harris, 2002; Human Rights Watch, 2007; Klaaren and Ramji, 2001; Kollapan, 1999; Landau et al., 2005). How are we to understand racism in the new South African context? How are we to interpret the racialization of 'others' and their experiences of discrimination and exclusion? This paper addresses these questions in the context of recent migration into the country and the racist abuse suffered by members of the 'black minority' who have migrated to the new South Africa from other African countries.

Post-apartheid South Africa was built on a culture of inclusiveness, tolerance and human rights, embodied in its 1996 Constitution. However, as this paper shows, black South African citizens in particular exhibit high levels of xenophobia towards fellow Africans subjecting them to different forms and degrees of prejudice and discrimination. The paper urges us to move away from 'colour' racism (black-white model) as a single overarching factor shaping racial and ethnic relations to examine the interplay of difference, diversity and cultural pluralism. At its heart, this paper argues that the racialization of African migrants- the other- and xenophobic sentiment are about the politics of access; a struggle for political and socio-economic resources.

\subsection{Xenophobia the New Racism?}

Xenophobia is defined by the World Conference Against Racism, Racial Discrimination, Xenophobia and Related Intolerance as, 'attitudes, prejudices and behaviour that reject, exclude and often vilify persons, based on the perception that they are outsiders or foreigners to the community, society or national identity' (WCAR, 2001). It encompasses the ethno-linguistic and cultural identifiers that form the basis of distrust and suspicion of the other (Nyamjoh, 2006). Unlike old racism which is based on discriminatory treatment at the hands of a race (a biological group) different to one's own, xenophobia can be linked to new racism which is based on the discriminatory treatment of the 'other', on the basis of the other's national origin or ethnicity. New racism isa, 'shift in racism, from notions of biological superiority, to exclusion based on cultural and national difference' (Ibrahim, 2005). It dispenses with the notion of superiority and instead the focal point is difference. As Babacan et al. (2009) argue, 'the proponents ofnew racism claim that they are not being racist or prejudiced, nor are they making any value judgments about the "others", but simply recognising that they [the others] are different'. This 
difference forms the basis for 'legitimate' and contemporary concerns of issues that are generalised as posing a threat to the values and beliefs that are cherished by the community (Dijk, 2000). As Wieviorka (1995) explains, 'racism no longer means relations of domination, but rather the setting apart, the exclusion (and in extreme cases the destruction) of races (cultures and ethnic group) that are thought to pose a threat.'According to Duffield (1996), this justification of exclusion of certain groups of people has 'modernised racism and made it respectable'.

Parallels can be drawn between xenophobia and new racism as they share similar outcomes of: perceiving the other as a threat; discrimination and exclusion based on the other's cultural origin; and the implementation of policies that lead to thetightening of immigration controls. However a distinctive difference between the two terms is that racism is an ideology with structural components. Rules, laws, regulations and institutions are formulated and created to reproduce racist ideology. Under xenophobia institutions have been used to exclude the other. They were not established to reproduce xenophobic sentiment. The relationship between xenophobia and racism can be located in South Africa's political past. Herein lies one of the contributory factors as to why black South Africans exhibit xenophobic sentiment.

\subsection{Historical Political Context of South Africa}

Post-apartheid South Africa became a favorable destination for immigrants lured by the attractiveness of a dynamic economy andhuman rights protection where principles of tolerance, equality and the respect of human rights are enshrined in the South African Constitution [section 7(1) of the Bill of Rights]. Although the Preamble declares that, 'South Africa belongs to all who live in it; united in our diversity' (ibid), widely interpreted to mean that it guarantees and promotes the respect of human rights of everyone within the country, the harsh reality is that migrants have encountered a society grappling with the legacy of apartheid.

From its formation as the Union of South in 1910, South Africa has been a deeply divided society where exclusion and was firmly established in its political and social fabric, entrenched by racist ideology. The then Prime Minster of the Union of South Africa J. C. Smuts stated 'racial separation [was] imperative' (Deegan, 2001) and when the white minority National Party came into power in 1948, apartheid became the official government policy. Legislation was designed to separate and deny the black majority from enjoying the same political and economic rights as white South Africans. Through the implementation of the Population Registration Act No. 30 of 1950 people were categorised into three racial categories: white, black, or coloured (either of mixed decent, or a subgroup of Indians/Asians). The Group Areas Act, Act No. 41 of 1950- forced the physical separation between the races through the creation of different residential areas for different races (Boddy-Evans, 2005). Through the creation of Bantustans -and the development of the 1951 Bantu Authorities Act, 1970 Bantu Homelands Citizenship Act, and 1971 Bantu Homelands Constitution Act-black South Africans were effectively not citizens of the Republic and therefore did not have the same political and economic rights as white South Africans.

Although the transition to democracy in South Africa ushered in the formal removal of racial discrimination that formed barriers to people accessing their political, social and economic rights, it did not eradicate inequalities. For instance, even though it brought South Africans into closer contact with each other by removing legislative barriers, this increased 'contact' does not amount to greater racial integration. Contact occurs within a context of unequal power relations in which 'whiteness' continues to be privileged over 'blackness'. 'The result is that white people tend to benefit more from contact with the racial 'other' than black people. They [black South Africans] in turn experience this contact as reinforcing their expectations of continued white dominance and privilege' (Vincent, 2008). The effects of the apartheid system are still evident today with poor black South Africans still living in shacks surrounding urban areas. Illiteracy rates are high with around $24 \%$ of adults over 15 years old (6 to 8 million adults are not functionally literate); teachers in township schools are poorly trained, with matric pass rate low in the townships. While $65 \%$ of whites over 20 years old and $40 \%$ of Indians have a high school or higher qualification, only $14 \%$ of blacks and $17 \%$ of the coloured population have higher education (South Africa, 2010). Racial tensions exist in employment with the percentage of blacks in top management positions increasing to $9.5 \%$ by 2006 (Fin24, 2007). The increase in unemployment, HIV/AIDS, crime, the ever growing gap between rich and poor, coupled with the African National Congress (ANC) struggling to meet the high expectations it set when it came into power in 1994, have culminated in creating a disempowered population.

The discrimination experienced by black South Africans because of their race should in theory make black South Africans in particular more sensitive and sympathetic to the plight of their fellow Africans. However in a survey carried out by the South African Migration Project when asked if migrants should be afforded rights only 35\% of 
respondents stated that they should (McDonald et al., 1998). It is against this backdrop that African migrants find themselves targeted by black South Africans. As this paper shows, fellow Africans seeking refuge, asylum or an opportunity to improve their economic prospects and life within the borders of South Africa are racialized targets for exclusion and violence. The experience of African immigrants is further compounded by the fact that citizenship is permeated with notions of new racism.

\subsection{Exclusionary Citizenship}

In forging a nation out of a multicultural and multi-ethnic society South Africa could not rely on common culture or ethnicity to create its 'imagined community' (Peberdy, 2001). As such it focused on citizenship as the unifying force. Imbued in the concept of citizenship is a sense of belonging and ownership that provides and guarantees access to state resources. In creating this notion of inclusiveness those that did not meet the criteria were effectively excluded. Smith (1991) argues that the 'idea of citizenship creates a sense of minimal reciprocal rights and obligations among members and the correlative exclusion of outsiders from those rights and duties'. So in defining itself, South Africa had to define who or what was to be excluded from the nation. Citizenship therefore forms the grounds for exclusion by drawing boundaries between insiders and outsiders.

National identity in the new democratic South Africa has therefore been built on citizenship. AccesstoState and public resources is determined by citizenship and protected by legal instruments. For this reason the Constitution, Whist some rights are held by all regardless of nationality others are for citizens only.

Therefore, according to the politics of access only citizens have the legitimate right to access the fruits of this newly founded democracy. Stripped of their citizenship rights under apartheid, black South Africansnow enjoy full citizenship in the new South Africa. In spite of this, the majority of South Africans realised that their constitutional rights have been slow in delivering the material benefits of citizenship. The economic policies embraced by the South African government through the Redistribution and Development Program from 1994 to 1996 and the Growth, Employment and Redistribution strategy from 1996 onwards did not build houses fast enough, nor alleviate unemployment currently at $40 \%$. (CORMSA, 2008). Xenophobia therefore becomes an expression of disillusionment of the government's ability to deliver, andthe 'other' becomes the target of frustrations. Unwittingly citizenship defined in racial terms has been used to exclude the 'other' black African immigrants.

Furthermore xenophobia undermines concepts such as the rainbow nation. Former Archbishop Desmond Tutu coined the term 'rainbow nation', a metaphor denoting unity in South Africa based on its multicultural make-up (Habib, 1996). This succeeded in unifying the nation as evidenced by the survey carried out by the Centre for Policy Studies which found that: $70.9 \%$ of blacks, $74.6 \%$ of coloureds, $71.5 \%$ of Asians and $68.4 \%$ of whites identified themselves as proudly South African; and $72.5 \%$ of blacks, $69.8 \%$ of coloureds, $77.4 \%$ of Asians and $67 \%$ of whites identified themselves as being part of the rainbow nation (Kornegay, 2005). The post-apartheid government had succeeded in creating solidarity in a fractured society. However only $28.4 \%$ of black South Africans identified themselves as African (Gibson, 2006). This brings into question whether black South Africans have fully embraced the spirit of ubuntu, -togetherness- which extends to and includes all humans irrespective of race, national origin or ethnicity. Instead of being all-inclusive, ubuntu is extended only to members of the rainbow nation and excludes foreigners particularly those from the African continent.

\section{Method}

Fieldwork was conducted in four two-month research trips to South Africa; April to May 2005, April to May 2006, August to September 2006 (Note 1), and August to September 2007. Data was gathered from interviews, official statements, mandates, speeches and policy initiatives made by migrant non-governmental organisations on their websites, in press releases and newspaper articles. The validity of the data provided was cross referenced with surveys conducted by the Forced Migration Studies Program, the South African Human Rights Commission and Lawyers for Human Rights, Institute for Democracy in South Africa, Human Rights Watch and the Southern African Migration Project (Note 2). In relation to the media, data was gathered from the print and radio mediums. The research focused primarily on the print media's coverage of migration related topics, by conducting textual analysis of newspaper articles from English language papers namely, the Star, Sunday Times, Mail and Guardian, Sowetan and the Cape Times, between 1994 and 2009. Apart from identifying keywords in headlines, the language and imagery used in the articles portrayal of immigration and immigrants was analysed, following the methodological approach employed by Danso and McDonald (2000). In relation to radio, archived material of transcripts of discussions on immigration on Radio 702 and SAFM were analysed, paying particular attention to radio coverage following large scale attacks on migrants. 
In order to elicit views from professionals within the field, interviews were conducted with eight members of four migrant-led non-governmental organisations; two prominent religious leaders; and seven coordinators of leading South African agencies advocating the rights ofmigrants. To obtain the views and experiences of migrants and South African citizens fifteen black South Africans (consisting of 3 men and 3 women aged between 30 and 40 years of age, 2 men and 2 women aged between 40 and 55 years of age, and 5 young men between 18 and 30years of age), six Congolese women (aged between 25 to 40 years); seven Somalis women (also aged between 25year and 40years); and three immigrant men (aged from 25 to 45years).

Access was provided by gatekeepers within the migrant associations and interviewees were contacted by means of phone calls and emails explaining the purpose of research, the reason they had been identified as vital contributors, and the theme of questions to be asked. These questions ranged from: how they define xenophobia and racism; their experience of xenophobia; and who they believed perpetuated xenophobic sentiment. Face to face semi-structured interviews, using open-ended questions were arranged with these respondents in order to elicit their views. In circumstances where they were not available telephone interviews were conducted instead. The duration of the interview was determined by the availability of the respondents lasting a minimum offorty minutes. As it was not possible for the Congolese and Somali women to set aside a definite time for the interview, the researcher had to interview them in their homes which would at times take up an entire day.

As xenophobia is an emotive subject great care was taken to reduce any unintended or unanticipated consequences of the research. A letter of introduction confirming the identity of the researcher and nature of the research was produced at the beginning of all interviews. Follow up calls and emails were sent after the interview thanking the respondents for their participation.

In order to help improve the reliability and validity of the study, data was collected via non-participant observations to supplement data collected from interviews. As Wimmer and Dominick (2006) argue, 'observation is not dependent on the subject's willingness or ability to report their behaviour'. Unlike interviews which by their very nature elicit particular information from respondents, guiding participants to provide specific responses, non-participant observations allows for the study of the phenomenon in its natural setting. Those being observed were informed of the presence of the researcher, and therefore the researcher acknowledges that her presence would inadvertently affect their behaviour and the results obtained (Note 3).

Denscombe (1998) points out that the disadvantage of qualitative research is that it is "bound up with the self of the researcher" and therefore subject to researcher bias. This study does factor in the researcher's bias and therefore became an exercise in reflexivity. Having lived in South Africa as a migrant for sixteen years, had contact with migrant communities and experienced first-hand hostility from some South Africans, the researcher had come to perceive the treatment of foreigners as a lack of awareness and misconceptions on the part of South Africans of who foreigners are and their purpose in the country. It is these very misconceptions that the study seeks to deconstruct in order to provide an understanding of xenophobia and racism.

Even though the researcher understands Sotho- one of the eleven official languages, two translators were required for South African respondents who did not speak English and the Somali nationalsinterviewed. Accuracy the 'extent to which a translation matches its original' (Gile, 1991) is essential when translators are used. Identifying an impartial translator was challenging as at times s/he did not directly translate the question posed or the response provided. Kalina (2002) argues that in order for the translator to 'represent fully the original speaker's interests and intentions, it is essential that the translator identifies and understands cultural and linguistic issues'. To overcome some of these issues, the researcher identified two people with the appropriate vocational experience of translating who had been used by other organisations. Wadensjo (1998) identified that one of the challenges for translation is finding out the hidden meaning(s) behind the speaker's actual intentions. This was addressed by posing the same question in different ways. Through the continual questioning of the respondent the researcher was able to ascertain that questions and responses were being effectively translated. The translator used the English word "xenophobia" from which the respondent immediately inferred meaning. This meant that the researcher and the translator did not impose their own inferences on the term. The researcher did not encounter difficulty in mobilising the term xenophobia in interviews as one of the aims of the research was to gain an understanding of the respondent's conceptualisation of xenophobia.

\section{Everyday Racism and Violence against Migrants}

From the $11^{\text {th }}$ of May 2008 to the $21^{\text {st }}$ of May 2008, Gauteng province witnessed two weeks of sustained violence against foreigners leaving $62 \mathrm{dead}, 22$ of whom were South African, and over 150,000 immigrants displaced (CORMSA, 2007). However violence towards foreigners by black South Africans is nothing new. From 1998 to 2008 there have been consistent aggressive attacks on foreigners in the country ranging from 
verbal abuse to physical assaults to murders.

In 1998 three foreigners were thrown off a moving train in Pretoria by South Africans returning from a rally on unemployment (Crush, 2001). In the same year, a Rwandan refugee was beaten up by a taxi driver because he was foreign and received cuts and bruises to his face, ear and body (ibid). The South African Broadcasting Corporation Two Way Programme reported that 30 refugees were killed in 1999, and one refugee had acid poured over his entire body (SABC, 2001). In August 2000 residents of Zandspruit Natal burnt down shacks of Zimbabwean foreigners living in the settlement (Parsely, 2008) (Note 4). A Sudanese refugee James Diop was seriously injured after being thrown from a train in Pretoria by a group of armed men in 2001 (Lefko-Everett, 2008). In the same year, Cape Town City Councilrecorded 22 stabbings of migrants attacked because they were foreign (Harris, 2002). Zimbabwean and Somali refugees were beaten in Bothaville-Free State in 2005 (CORMSA, 2007) (Note 5). Somali shop owners were chased out a township outside Knysna in 2006 and at least 30 shops were damaged (ibid) (Note 6). In August 2007, 13 Somali shopkeepers were found murdered in their shops in Cape Town. Nothing had been taken (CORMSA, 2008). Shops owned and staffed by non-nationals were attacked and looted in the Western Cape a month later. 40 non-nationals fled and were temporarily accommodated at mosques and with friends (ibid).

The experience of migrants in the country is not unique to South Africa. A comparative study by the South African Migration Project called the National Immigration Policy Survey of 2001-2002, of the five South African Development Countries found that in Southern Africa, next to South Africa, Botswana and Namibia expressed the highest anti-immigrant sentiment towards African migrants (Note 7).

\subsection{An Identifiable Group}

A distinctive feature of these cases is that the other is the foreign national. In the case of South Africa foreign nationals targeted are black Africans with those from Europe and South East Asia being excluded. This begs the question of whether there is an identifiable group that perpetuate xenophobic sentiment and violence?

A survey on public attitudes and perceptions conducted by the South African Migration Project in 1998 was unable to identify a 'typical' profile of a xenophobic person (Crush, 2008). Negative attitudes towards immigrants were held by all South Africans irrespective of race. This was in keeping with the National Immigration Policy Survey which found that, "the poor and rich, the employed and unemployed, black and white...all express similar attitudes’ (Crush and Pendleton, 2004).

Table 1. Respondent Profile by Race and Gender

\begin{tabular}{llll}
\hline Race & Male (\%) & Female(\%) \\
\hline White & 14 & 12 \\
Black & 70 & 71 \\
Coloured & 12 & 13 \\
Indian/Asian & 4 & 4 \\
Number & 1802 & 1798 \\
\hline
\end{tabular}

2006, SAMP Xenophobia Survey

Therefore in 2006 South African Migration Project conducted a nationally representative survey of respondents from all nine provinces in South Africa (Table 1). They assigned a score to each person surveyed in order to differentiate between groups. On a scale of zero ' 0 ' extremely xenophobic to ten '10' not xenophobic at all they found that coloured respondents exhibit the highest levels of xenophobiaat 3.57 compared to whites at 3.91, blacksat 4.01, and Asians/ Indians at 4.13 (Crush, 2008).

Unlike Crush (2001) who purports that one of the reasons white South Africans hold more xenophobic views is that, 'few whites regularly interact with large number of non-nationals' (Crush, 2001), it is not the remit of this paper to analyse why xenophobic sentiment is high amongst whites. Instead this paper investigates why black South Africans express their prejudice through violence. 
Table 2. Monthly Household Income by Race

\begin{tabular}{lllll}
\hline & White (\%) & Black (\%) & Coloured (\%) & Asian/Indian (\%) \\
\hline Less than R3 000.00 & 7 & 59 & 41 & 17 \\
R3 000.00 - R5 999.00 & 10 & 14 & 20 & 22 \\
R6 000.00 -R8 999.00 & 12 & 6 & 10 & 11 \\
R9 000.00 - R11 999.00 & 7 & 3 & 6 & 10 \\
R12 000.00 - R15 999.00 & 9 & 2 & 3 & 9 \\
R16 000.00 - R19 999.00 & 9 & 1 & 2 & 6 \\
R20 000.00 or more & 13 & $<1$ & 1 & 6 \\
No answer & 34 & 14 & 18 & 18 \\
Number & 462 & 2523 & 441 & 141 \\
\hline
\end{tabular}

2006, SAMP Xenophobia Survey

From the same 2006 survey sample (Table 2), it was found that those in income groups of R8,999.00 per month were more xenophobic with scores ranging from 3.6 to 3.9 than those in the R16,000.00 to R19,999.00 income category who scored between 4.0 and 4.5 . Of this group $79 \%$ of black respondents earned less that R8,999.00 followed by $71 \%$ of Coloureds, $50 \%$ of Asians and $29 \%$ of whites.

Table 3. Respondent Profile by Race and Class

\begin{tabular}{|l|l|l|l|l|}
\hline Race & White $(\%)$ & Black $(\%)$ & Coloured $(\%)$ & Asian/Indian $(\%)$ \\
\hline Lower class & 3 & 46 & 19 & 9 \\
\hline Working class & 25 & 20 & 43 & 36 \\
\hline Middle class & 50 & 27 & 32 & 36 \\
\hline Upper middle class & 15 & 3 & 3 & 6 \\
\hline Upper class & 4 & 1 & $<1$ & 7 \\
\hline Don't know & 4 & 4 & 3 & 6 \\
\hline Number & 462 & 2527 & 442 & 141 \\
\hline
\end{tabular}

2006, SAMP Xenophobia Survey

From the respondents (Table 3), the lower class and the upper class exhibited 3.72 levels of xenophobia, with the middle class exhibiting 4.1. Of this group $66 \%$ of blacks and $62 \%$ of coloureds described themselves as 'lower' or 'working class' compared to $45 \%$ of Asians and 28\%whites. 50\%whites, 36\% Asians, $32 \%$ coloureds and $27 \%$ blacks described themselves as middle class (Crush, 2008).

Taken together with the fact that unemployment officially rose from $22.7 \%$ to $30.5 \%$ in 2002 (Statistics South Africa 2002), with unofficial records placing it at $40.3 \%$ in 2002 (Department of Trade and Industry, 2002) and at $40.7 \%$ (Altman) in 2005, socio-economic factors play a vital role in increasing xenophobic sentiment. As Nyamjoh points out, economic disparity between the rich and the poor is drawn along racial lines in South Africa (2006).

\subsection{Motivations for Racist Violence: Migrants Steal Jobs}

The perception amongst all South Africans that migrants steal jobs rose from 56\% in 1999 to $62 \%$ in 2006 (Crush, 2008) coincides with the increase in unemployment. Tshitereke (1999) suggests that in the post-apartheid epoch, when people's expectations were heightened, the realisation that delivery is not immediate has meant that discontentment and indignation are at their peak thereby providing the perfect breeding ground for xenophobia to take root and flourish. Abdul Hassan, chairperson of the Somali Association of South Africaplaces this disillusionment at the feet of the government.

They [South Africans] didn't get what was promised to them after the 1994 elections. So they 
think that the little that they have [is] being shared by [people] from African countries who have come to South Africa. They [South Africans] don't want that (Note 9).

These internal socio-economic challenges heighten the perception that migrants place an immense burden on already scarce resources. This position is in keeping with international studies that reveal that migration poses 'substantial economic costs and strains to infrastructures in housing, education, transportation and on welfare providing institutions' Terrif (1999). With South Africa struggling to meet the needs of its own people, it will struggle to allocate resources to foreigners in the country. In this context, Tshitereke (1999) notes, people often create a 'frustration-scapegoat' to blame for on-going deprivation and poverty. Migrants become scapegoats, because they are perceived as threats to jobs, housing, education and health care (Morris, 1998). The inability to realise their full citizenship rights coupled with the economic challenges facing the state creates a vulnerable group in society. In South Africa it is the black unemployed citizens living in urban informal settlements.

This is not unique to South Africa. Socio-economics plays a central role in triggering xenophobic sentiment. The Unification of East and West Germany brought together two uneven political and socio-economic entities- the successful West with the less advantaged East. Owing to what Watt (1997) calls "the structural adaptation of the German economy" there was an increase in unemployment with two million West Germans and one million East Germans needing jobs. This manifested itself in attacks on nationals from Eastern Europe. The perpetrators were young people that had not benefited from what Watt (1997) refers to as the modernisation process. They were a vulnerable group with poor education and limited access to gainful employment. A similar situation is evident nowadays in Greece where the economic crisis with the resulting high levels of unemployment amongst young people and of increasing poverty has resulted in the rise of far-right groups and parties like the Golden Dawn who encourage hate speech and hate crime against the 'other', who are seen as a 'threat' to Greek's access to resources.

A study conducted by the Centre for the Study of Violence and Reconciliation further emphasized that, 'the targeting of African foreigners is a product of proximity as they [both] reside in areas [with high levels of poverty].' (Valji \& Fuller, 2008). The Human Sciences Research Council have identified reasons why xenophobic violence occurs in urban informal settlements. Owing to their socio-economic circumstances, black South Africans establish homes in the informal settings surrounding major cities. Likewise immigrants, particularly refugees struggling to access housing and experiencing delays in gaining refugee status, also end up setting homes in these urban informal settlements (HSRC, 2008). This is why the Consortium for Refugees and Migrants state that xenophobic violence occurs in areas of 'high but not the highest levels of economic deprivation and high levels of informal housing' (2008).

The presence of the foreigner, who is in close proximity, is deemed a threat to black South African's access to resources particularly in the informal sector as documented by the South African Broadcasting Corporation's (SABC) Special Assignment programme (2006):

It's in the market places that hostility towards the Somalis plays out. Their asylum status in South Africa means they can't get formal jobs so they have to make it in the informal sector. This brings them into direct competition with other poor South Africans also trying to eke out a living.

Migrants have themselves exacerbated these perceptions as noted by the Special Assignment programme (2006):

Somalis sell their goods at lower profit margins than their South African competitors relying on volume to earn an income. When we looked at prices, the differences were striking. In this stall, jeans sell for one hundred and forty [Rands]. In the Somali stall next door, the same jeans cost one hundred and twenty [Rands]. This is the root of the growing resentment.

Offering competitive prices has been perceived as stifling competition, a belief shared by a local South African Hawker- Lisolomzi Alex Mbham who stated:

They are spoiling our business because they [have taken] our business in our location even in the township. People don't want to buy from us because our prices are higher than the Somalis.

Somalis purchase their products -in bulk at wholesale prices enabling them to sell them at lower prices (Note 10). Such actions by Somali shopkeepers is met with hostility and a sense of unfairness from local South African Hawker Associations. Khaya Cwayi- Chairperson of the Siyaka Business Trust (Special Assignment, 2006) said:

They run their business and demoralize the existing business in Masiphumelele. We can't accept that. That is not good enough. That is not fair. They don't actually give the chance to other people to run their business. 
It is to this background that Ashraf Mahomed of the South African Human Rights Commission (Special Assignment, 2006) stated:

In a context where we are grappling with social issues, issues of diversity, racial integration, economic and social rights and competition for resources; it is not surprising that there would be a sense of territoriality [the perception that] the other is going to displace us and remove our livelihoods. [This] may have contributed to an increase in xenophobia.

The Consortium for Refugees and Migrants has developed the field further by highlighting the fact that black South Africans are not a homogeneous group in their expression of xenophobic sentiment. They argue that, 'local community leaders and aspirant leaders mobilize residents to attack and evict foreign nationals as a means of strengthening their personal political or economic power within the local community. In many instances violence has been organised by business owners intent on eliminating competitors' (2008) This suggests thatxenophobia is deliberate and organised. This is an example of a category of black South Africans 'demonstrating their political [or] economic power by discriminating against a less category of people -immigrants' (Landau et al 2005).

Evidence from the Centre of Violence and Reconciliation and the University of Witwatersrand show that migrants have positively contributed to the economy by buying goods and services, and importing skills (Maharaj, 2002). Through enterprise and entrepreneurship, migrants have also created job opportunities for South Africans in the small and medium sectors. Furthermore, a study conducted by the University of Witwatersrand in inner-city Johannesburg in 1998 found that non-South Africans were far more likely to hire someone to work for them than their South African counterparts. 20\% of black South Africans surveyed in Johannesburg reported having paid someone to work for them compared to $34 \%$ of the migrants surveyed. Furthermore, 67\% of those hired by migrants were black South Africans (Landau et al., 2005). Similar studies in Durban and Cape Town identified the positive economic impact of immigration. Maharaj (2002) argues that, 'immigrants are net contributors, not parasites'. Many pay tax and through their entrepreneurship make positive contributions to the local economy. Ten years on, the Centre for Development and Enterprise carried out research in 2008 on migrant-owned businesses in Johannesburg. They found that: migrants are more than twice as likely to be self-employed; $12 \%$ of immigrants employ nearly four people each mostly in the informal sector and many of those they employ are South Africans (CDE, 2008). This supports the results of the survey conducted by the Forced Migration Studies Programme on migrants in inner-city Johannesburg in 2005 (Landau et al., 2005).

However this is only a small percentage of migrants. In an environment where refugees and asylum seekers have to wait long periods for their permits, they make a living for themselves within the informal sector. It was estimated that in 2002 the informal sector (Note 11) contributed 7.1\% of the gross domestic product (GDP) and accounts for $22.3 \%$ of all jobs (Davies \& Thurlow, 2009). This only serves to fuel perceptions that migrants are increasing competition and 'taking jobs'.

\section{Institutional Xenophobia/Racism}

\subsection{The Police}

Black non-South Africans living or working in the country report having been stopped by the police far more frequently than South Africans (Nduru, 2005). A survey conducted by the University of the Witwatersrand, based in Johannesburg, found that $71 \%$ of refugees interviewed said they were stopped by the police, compared with 47\% of South Africans (Valji, 2004). Similar results were found by the Special Assignment Programme in 2006 (Special Assignment, 2006).

Reasons for apprehending a person and the process of deciding their legal status has been described as archaic and dehumanising by the South African Human Rights Commission. The criteria used to identify foreigners include traits such as 'skin colour, height, and presence of inoculation marks' has also meant that South Africans get arrested and detained (Valji, 2004). '30\% of people arrested by the police on suspicion of being illegal migrants are [black] South Africans. They are picked up because they are too dark and they happen to be in the wrong place at the wrong time', observed Professor Neocosmos (ibid).

The 'identificatory' methods purportedly used by the Internal Tracing Units of the South African Police Service in trying to establish whether a suspect is an illegal or not, are language, accent, the pronouncement of certain words (such as Zulu for 'elbow', or 'buttonhole' or the name of a meerkat). Some are asked what nationality they are and if they reply 'Sud' African this is a dead give-away for a Mozambican, while Malawians tend to pronounce the letter ' $r$ ' as 'errow'. Appearance is another factor; hairstyle, type of clothing worn as well as actual 
physical appearance. For Mozambicans it is the vaccination mark on the lower left forearm, while those from Lesotho tend to wear gumboots, carry walking sticks or wear blankets (in the traditional manner), and also speak slightly different Sesotho (Minaar \& Hough, 1996). The biological-cultural features of hairstyles, accents, vaccination marks, dress and physical appearance signify difference and play a common role in prompting racist actions. Biological-culturalmarkers are significant in generating xenophobia and racism because they point out whom to target. However, what they signify and how they have come tosignify this must also be explained in order to comment on reasons for xenophobia and itsasymmetrical application to certain (black) foreigners. Although the visible otherness offoreign Africans seems to be an important factor behind local hostility, this is not asufficient explanation for the asymmetrical xenophobia directed towards certain groups of African foreigners, who relative to African foreigners, appear to be at a lower risk for violence. One possible way of understanding why black foreigners are targets of violence is topostulate a new hypothesis, one that situates xenophobia within South Africa's transitionfrom a past of racism to a future of nationalism (Harris, 2002).

Ahmed Dawlo (Note 12) the National Director of the Somali Association of South Africa argued that xenophobia must be understood against the backdrop of apartheid. He stated that:

Xenophobia is a child of racism. It is a product of apartheid that has continued into the new South Africa. It is black immigrants from the African continent and not other groups of immigrants that are targeted.

The treatment of black immigrants by black South African is indicative of internalised racism. Weissglass argues that "patterns of internalizing and transferring racism (insults, criticism, slurs, and violence) are rooted in genocide, slavery, subjugation, conquest, and exploitation. When people are hurt and not allowed to heal through emotional release, they are pulled to re- enact the hurt on someone else' (Wiessglass, 2001). This follows the logic that the abused becomes the abuser. Black South Africans were greatly disadvantaged by the apartheid regime that objectified them as inferior. Legislation was used to ensure that they were treated and conceptualised as second-class people, unworthy of rights. The exclusion that they suffered is now projected onto immigrants. Nyamnjoh argues that immigrants are targeted because of, 'their blackness, by a society where skin colour served as an excuse for whole categories of discriminatory practises' (Nyamjoh, 2006).

All the immigrant respondents in this research identified government officials as extremely xenophobic. When asked who she thought exhibited the worst signs of xenophobia, Sulega Dahir (Note 13) identified 'the police'. 'We make complaints-nothing happens. They check ID and permit papers. If they are not recognised the individuals are arrested' (ibid).

The carrying of identification is linked to the apartheid regime. In the same way that black Africans had to carry documentation as proof of their legal status under Apartheid, so too do immigrants. If an officer suspects that the individual is illegal, s/he should accompany the person to retrieve their ID or documentation (Human Rights Watch, 1998). In practice however, suspects are immediately arrested. The police have been reported to routinely confiscate and destroy refugees' documents in order to justify arresting them as illegal migrants (Nduru, 2005). For example, a legal migrant with a work permit stated that:

My documents were destroyed by the police at Diepkloof Zone 5 on the $26^{\text {th }}$ November. Now I have no documents. I was never given the chance to tell the police or Home Affairs about my documents. I'm afraid to get beaten (ibid).

Irrespective of the fact that the police are clearly violating the human-rights of migrants, one of the justifications for their action is based on the myth that migrants commit crime. Arresting migrants is one of the measures taken by the police to reassure the population that steps are being taken to address the high levels of crime in the country. In March 2000 over 1000 police and military personnel were deployed in Hillbrow to search 22568 vehicles, 293 buildings and over 205324 people. Called Operation Crackdown- approximately 7068 people were arrested on suspicion of being illegal migrants of whom 7000 were sent to the deportation centre (Harris, 2001). Similar action was taken on the $1^{\text {st }}$ of February 2008, when the police arrested 500 Zimbabweans who had sought refuge in the Central Methodist Church in Central Johannesburg on the grounds that they were not only suspected of being illegal migrants staying in the building, but as Captain Bheki Mavundla the police spokesman stated, '... we were responding to public complaints about robbers who were in the church' (Kharsany, 2008). These actions by the police only serve to reinforce the perception that migrants are linked to crime.

Assertions made by the media that migrants are 'flooding' and 'swarming' into South Africa (Danso \& McDonald, 2000) have also fuelled police action. The number of illegal migrants is unknown and as such figures are highly contested. The South African Institute of International Affairs calculated that there were 5 million illegal migrants in the country (Solomon, 2001). Buthelezithinks there are between $2.5-5$ million and bases his 
ascertains on the number of repatriations, illegal border crossings, number of people who have overstayed their tourist and study visas, and information supplied by the South African National Defence Force and the South African Police Service (Reitzes, 1998). The South African Police Service placed the figure at 2- 3.5 million (5-8\% of South Africa's total population). The Freedom Front estimated 8 million (Solomon, 2001). The Human Science Research Council claim there are about 12million, implying that one in four South Africans is an illegal migrants (ibid). Estimates in 2008 ranged from between 3 million to 15 million (CORMSA, 2008).

These figures have been used to fuel anti-migrant sentiment. For instance the former Home Affairs Minister Mongosuthu Buthelezi used these figures to politicise the tightening of immigration controls, whilst the AfricanChamberof Hawkersand IndependentBusinessmen use these fears in their campaigns against foreigners (Harris, 2001).

\subsection{Department of Home Affairs}

The Department of Home Affairs is at the forefront of handling all migrant related issues dealing with permits and border control. Immigration officers are accused of using excessive force, engaging in acts of bribery and abusing the human rights of migrants. Dosso Ndessomin (Note 14) illustrated that the possession of a refugee identity book has not guaranteed access to rights afforded refugees.

This is my ID [holds up the red Refugee identity book]. It is not known by everybody. When you are given your refugee ID it comes with a list of entitlements. But the problem is at implementation level because services and institutions do not know about [these entitlements] (ibid).

He provided an example of the problems faced with Immigration Officers at South African airports upon his return from international trips.

At the airport you are asked, 'are you a resident?' you say, 'yes!' Show me that you are a resident.' You show him the ID. 'Is this a green paper? I didn't stamp this.' My travel document is stamped by the department of Home Affairs signed by the Director of Refugees. But they [the immigration officers] don't care (ibid).

He also spoke of the procedural problems of having a refugee permit.

Your refugee permit is extended every two years. You apply for the ID. It takes a long time before a new one is sent. This one [pointing to his ID book] expired in February 2007. It is now September 2007. It has expired- dead! There is nothing I can do with it. When you go to an institution like the bank and say 'I want to make a transaction', they say 'your ID has expired we can't [provide] you a service'; Ihave banked my money and I cannot get it. The laws all refer to a green ID and proof of residence. It is not easy for refugees (ibid).

It took the government seven years from 1995 to develop the post-apartheid legislation governing Immigration: Immigration Act No. 13 of 2002. Prior to 2000, legislation drafted by apartheid law makers - the Aliens Control Act No. 96 of 1991 and its amendment No. 76 of 1995- was the only legislation governing the treatment of immigrants. Xenophobic sentiments were propagated through legislation and evident in the political discourse at the time. Former Minister of Home Affairs- Mongosuthu Buthelezi said:

If we South Africans are going to compete for scarce resources with millions of aliens who are pouring into South Africa, then we can bid goodbye to our Reconstruction and Development Program (Human Rights Watch, 1998).

He also stated that:

The employment of illegal migrants is unpatriotic because it deprives South Africans of jobs ... the rising level of migrants has awesome implications for RDP as they will be absorbing unacceptable proportions of housing subsidies and adding to the difficulties we will be experiencing in health care (Reitzes, 1998).

What is surprising is the fact that Mr Buthelezi was Minister of Home Affairs for ten years (1994-2004) and within that time the ANC did not officially endorsed nor challenge his exclusivist approach (Nyamnjoh, 2006). This can only imply that Buthelezi implemented a punitive policy which allowed the ANC to keep its distance whilst quietly approving it, with Buthelezi receiving most of the opprobrium from the policy.

\section{Concluding Remarks}

In the new South Africa, human rights, democratic principles and notions such as ubuntu have been defined 
narrowly for the benefit of South Africans only and have notbeen extended to include foreigners. 'Ubuntu' which means togetherness, is an idea based on humanness, that people realise their humanity through interaction with others (Lodge, 1999). Although 'ubuntuis the common foundation of all African cultures- a consciousness of belonging together' (ibid), the existence of xenophobia demonstrates an absence of tolerance for 'other' Africans.

As a result of its political transformation South Africa has become a victim of its own success. It became a magnet for nationals from African countries who came to the country to share in the fruits ofstable governance and enjoy the benefits of a larger dynamic economy. The state has had to absorb the consequences of poor or non-existent governance in African countries, whilst simultaneously contending with the legacy of apartheid and poor service delivery. This has created a disempowered populace not able to access or enjoy the material benefits promised by government, leaving migrant vulnerable in a country where race still place a role.

\section{References}

Altman, M. (2005). The State of Employment. In R. Southall, J. Daniel, \& J. Lutchmann (Eds.), State of the Nation. Cape Town, South Africa: HSRC Press.

Babaca, N., Gopalkrishnan, H., \& Babacan, A. (2009). Situating Racism: the Local, National and the Global. Newcastle, England: Cambridge Scholars Publishing.

Bhengu, M. F. (1996). Ubuntu: The Essence of Democracy, Cape Town: Novalis Press.

Blaxter, L., Hughes, C., \& Tight, M. (1996). How to Research. Buckingham, England: Open University.

Bloch, A. (2010). The right to have rights?Undocumented migrants from Zimbabwe living in South Africa. Sociology, 44(28), 233-250. http://dx.doi.org/10.1177/0038038509357209

Boddy-Evans, A. (2005). Apartheid Legislation in South Africa. African History. Retrieved November 17, 2007, from http://africanhistory.about.com/library/bl/blsalaws.htm

CDE. (2008, August 24). Immigrants in Johannesburg: Perception and Reality. CDE. Retrieved fromhttp://www.cde.org.za/article.php?a_id=321

CORMSA. (2007, June). Protecting Refugees and Asylum Seekers in South Africa. CORMSA. Retrieved from http://www.cormsa.org.za/wp-content/uploads/2008/06/crmsa07report.pdf

CORMSA. (2008, June). Protecting Refugees, Asylum Seekers \& Immigrants in South Africa. CORMSA. Retrieved from http://www.lhr.org.za/sites/lhr.org.za/files/Cormsa08-Final.pdf

Crush, J. (2001). The Dark Side of Democracy: Migration, Xenophobia and Human Rights in South Africa. International Migration, 38(6), 103-133. http://dx.doi.org/ 10.1111/1468-2435.00145

Crush, J. (2003). South Africa: Policy in the Face of Xenophobia. Migration Information Source. Retrieved from http://www/migrationinformation.org/Profiles.display.cfm?id=131

Crush, J. (2008). The Perfect Storm: The Realities of Xenophobia in Contemporary South Africa. Migration Policy Series, 50, 1-67. Retrieved from http://www.queensu.ca/samp/forms/form.html

Crush, J., \& Pendleton, P. (2004). Regionalising Xenophobia: Citizen's Attitudes to Immigration and Refugee Policy in South Africa. Migration Policy Series, 30. Cape Town, South Africa: SAMP.

Danso, R., \& Mcdonald, D. A. (2000). Writing Xenophobia: Immigration and the Print Media in Post-apartheid South Africa. Africa Today, 48(3), 115-137.

Davies, R., \& Thurlow, J. (2009, March). Formal-informal economy linkages and unemployment in South Africa. Cape Town, South Africa: HSRC Press. Retrieved from http://www.hsrc.ac.za/research/output/outputDocuments/5811_Davies_Formalinformallinkages.pdf

Deegan, H. (2001). The Politics of the New South Africa: Apartheid and After. Harlow, England: Longman.

Department of Trade and Industry (2002, February). Recent Employment Data from the Labour Force Survey. Thedti. Retrieved from http://www.thedti.gov.za/econdb/eoverviewlfsweb.doc>

Denscombe, M. (Eds.). (1998). Good Research Guide: For Small Scale Social Research Projects. Maidenhead, England: Open University Press.

Dijk, T. A. (2000). New Racism: A discourse analytical approach. In S. Cottle (Eds.), EthnicMinorities and the Media. Milton Keynes, England: Open University Press.

Duffield, M. (1996). The symphony of the damned: racial discourse, complex political emergencies and humanitarian aid. Disasters, 2(3), 173-193. 
FIN24. (2007, May 15). Government: We're not anti-white. Fin24 Retrieved May, 15 2007, from http://www.fin24.com/Business/Govt-Were-not-anti-white-20070515

Gibson, J. (2006). Overcoming Apartheid: Can Truth Reconcile a Divided Nation? New York, NY: Russell Sage Foundation. http://dx.doi.org/10.1080/0258934042000280698

Gile, D. (1991). A Communication Oriented Analysis of Quality in Non-literacy translations and interpretations. In M. L. Larson (Eds.), Translation: Theory and Practise: Tension and Interdependence. New York, NY: Binghampton.

Habib, A. (1996). Myth of the Rainbow Nation: Prospects for Consolidation of Democracy in South Africa. African Security Review, 5(6). Retrieved from http://www.iss.co.za/Pubs/ASR/5No6/Habib.html

Harris, B. (2001). A Foreign Experience, Violence, Crime, and Xenophobia during South Africa's Transition.Violence and Transition Series, 5, Johannesburg, South Africa: Centre for the Studies of Violence and Reconciliation. Retrieved from http://www.csvr.org.za/docs/foreigners/xenopobia.pdf

Harris, B. (2002). Xenophobia: A new Pathology for a new South Africa? In D. Hook, \& G. Eagle (Eds.). Psychopathology and Social Prejudice. Cape Town, South Africa: University of Cape Town Press.

HSRC. (2008, June). Citizenship, Violence and Xenophobia in South Africa: Perceptions of South African Communities. Human Sciences Research Council. Cape Town, South Africa: HSRC Press. Retrieved from http://www.hsrc.ac.za/Document-2807.phtml

Human Rights Watch. (1998). Prohibited Persons' Abuse of Undocumented Migrants, Asylum-Seekers, and Refugees in South Africa. New York, NY: Human Rights Watch.

Human Rights Watch. (2007). Keep Your Head Down: Unprotected Migrants in South Africa. Human Rights Watch, 19(3). Retrieved from http://www.org/reports.2007/southafrica0207/

Ibrahim, M. (2005). The Securitization of Migration: A Racial Discourse. International Migration, 43(5), 163-187.

Kalina, S. (2002). Quality in interpreting and its prerequisites: a framework for a comprehensive view. In G. Garzone, \& M. Viezzi (Eds.), Interpreting in the $21^{\text {st }}$ Century. Amsterdam, Netherlands: John Benjamins Publishing Company.

Kharsany, K. (2008, February 6). Refugees Return to Raided Church Amid Legal Wrangles. Mail, Guardian.

Klaaren, J., \& J. Ramji. (2001). Inside Illegality: Migration Policing in South Africa after Apartheid. Africa Today, 48(3), 35-47. http://dx.doi.org/10.2979/AFT.2001.48.3.34

Kollapan, J. (1999, October 7). Xenophobia in South Africa: the Challenge to Forced Migration. [Unpublished Seminar Paper, Graduate School]. Johannesburg, South Africa: University of Witwatersrand.

Kornegay, F. (2005). Research Report 106 Race and Ethnic Barometer: A Narrative Analysis of Findings from the Centre of Policy Studies Social Identity Survey. Centre for Policy Studies. Retrieved from http://www.cps.org.za/cps\%20pdf/RR106.pdf

Landau, L., Ramjathan-Keogh, K., \& Singh, G. (2005). Xenophobia In South Africa and Problems related to it. Forced Migration Paper $\quad$ Series, $13 . \quad$ Retrieved from http://www.migration.org.za/sites/default/files/working_papers/2009/13_Landau_et_al_Background_Paper. pdf

Lefko-Everett, K. (2008). Aliens, Migrants, Refugees and Interlopers: Perceptions of Foreigners in South Africa. ePoliticsSA. Retrieved from http://www.idasa.org.za/index.asp?page=output_details.asp\%3FRID\%3D1554\%26oplang\%3Den\%26OTID $\% 3 \mathrm{D} 5 \% 26 \mathrm{PID} \% 3 \mathrm{D} 44$

Li, J. (2008, May 24). News Analysis: What is Behind Xenophobia in S. Africa. China View. Retrieved from http://news.xinhuanet.com/english/2008-05/24/content_8240500.htm

Lodge, T. (1999). South African Politics since 1994. Cape Town, South Africa: David Philip.

Lohrmann, R. (2000). Migrants, Refugees and Insecurity. Current Threats to Peace', International Migration, $38(4), 4-22$.

Mahamba, M. (1993). Ubuntu and Democracy. Challenge, 16, June-July, 6-7.

Maharaj, B. (2002). Economic Refugees in Post-Apartheid South Africa: Assets or Liabilities. Implications for 
Progressive Migration Polices. Geo Journal, 56, 47-57.

Mcdonald, D., Gay, J., Zinyama, L., Mattes, R., \& Vletter, F. (1998). Challenging Xenophobia: Myths and Realities about Cross Border Migration in Southern Africa. Migration Policy Series, 7. Cape Town, South Africa: SAMP.

Minaar, A., \& Hough M. (1996). Causes, Extent, and Impact of Clandestine Migration in Selected Southern African Countries with Specific Reference to South Africa. Pretoria, South Africa: Human Sciences Research Council.

Morris, A. (1998). Our Fellow Africans Make our Lives Hell: the Lives of Congolese and Nigerians Living in Johannesburg. Ethnic and Racial Studies, 21(6), 16-36.

Nduru, M. (2005, August 22). SA doesn't roll out welcome mat for all immigrants. Mail and Guardian.

Nyamnjoh, F. B. (2006). Insiders and Outsiders: Citizenship and Xenophobia in Contemporary Southern Africa. London, England: Zed Books.

Parseley, J. (2008). We Are Not Treated Like People. The Roll Back Xenophobia Campaign in South Africa. Retrieved from http://www.odihpn.org/report.asp?id=2208

Peberdy, S. (2001). Imagining Immigration: Inclusive Identities and Exclusive Policies in Post-1994 South Africa. Africa Today, 48(3), 15-33.

Reitzes, M. (1994). Alien Issues. Indicators South Africa. 12, Summer, 7-11.

SABC. (2001, January 29). Two Way Programme. SABC. Johannesburg, South Africa: South Africa Broadcasting Association.

Sikita Da Silva, I. (2007, April 19). SA print Media Racist, Xenophobic? Bizcommunity. Retrieved September 20, 2008, from http://www.bizcommunity.com/Article/196/15/14321.html

Smith , A. D. (1991). National Identity. London, England: Penguin Books.

Solomon, H. (2001). Contemplating the Impact of Illegal immigration in the Republic of South Africa. Journal of Contemporary History, 26(1), 1-29.

South Africa. (2010). Education in South Africa. South Africa Info. Retrieved October 2009 from http://www.southafrica.info/about/education/education.htm

Special Assignment. (2006, November). Refugees Under Attack. SABC 3. Johannesburg, South African Broadcasting Association.

Statistics South Africa. (2002). Unemployment and Employment in South Africa. Pretoria, South Africa: Statistics South Africa.

Stephens, D. (2009). Qualitative Research in International Settings: A Practical Guide. London, Enlgand: Routledge.

Terrif, T. (1999). Security Studies Today. Cambridge, England: Polity Press.

Togral, B. (2011). Convergence of Securitization of Migration and 'New Racism' in Europe: Rise of Culturalisms and Disappearance of Politics, in Lazaridis, G. (ed) Security, Insecurity and Migration in Europe. Farnham. Ashgate.

Tshitereke, C. (1999). Xenophobia and relative deprivation. Crossings, 3(2), 4-5.

Valji, N. (2004, May ). Race and Reconciliation in Post-TRC South Africa. [Paper Presented at the Ten Years of Democracy Conference at Queens University Canada]. Retrieved from http://www.csvr.org.za/wits/papers/papnv3.htm

Valji, N., \& Fuller, R. (2008, May 2). Scarcity Sets Fire to Countries Xenophobic Tinderbox. Business Day.

Vincent, L. (2008). The limitations of 'inter-racial contact': stories from young South Africa. Ethnic and Racial Studies, 31(8), 1426-1451.

Wadensjo, C. (1998). Interpreting as Interaction. London, England: Longman.

Watts, M. W. (1997). Xenophobia in United Germany: Generations, Modernization, and Ideology. Basingstoke, England: Macmillan.

WCAR. (2001 February 18). Declaration on Racism, discrimination, Xenophobia and Related Intolerance against Migrants and Trafficked Person Asia Pacific NGO Meeting for the World Conference Against 
Racism, Racial Discrimination, Xenophobia and Related Intolerance. Tehran, Iran.

Weissglass, J. (2001). Racism and the Achievement Gap. St Paul's School Reform, 20(43), 49-55.

Wieviorka, M. (1995). The Arena of Racism. London, England: Sage Publications.

Wimmer, R., \& Dominick, J. (2006). Mass Media Research: An Introduction. Wadsworth, Canada: Cengage Learning.

\section{Notes}

Note 1. This particular research trip coincided with the August 2006 killings of Somali shopkeepers in Cape Town.

Note 2. SAMP is an international network of organizations founded in 1996 to promote awareness of migration-development linkages in the South African Development Community. It conducts applied research, provides policy advice and expertise, offers training and conducts public education campaigns on migration-related issues. See www.queensu.ca/samp/

Note 3. For instance when observing two different groups of respondents on different occasions, it was challenging to gage if they were tailoring their actions to suit the reason they were being observed. Conscious ofmy presence it was difficult to ascertain if their behaviour was guarded. I was however able to interviewer some of these participants individual away from the group. Blaxter (1996) also argues that the researcher must consider how his/her age, sex, and class impacts and contributes to research findings. On a reflexive note, the researcher observed how social status affects the conduct of research. Knowingthe researcher was from an institution based in the United Kingdom provided the researcher with legitimacy to conduct the research. As Stephens argues, 'overseas researchers can be perceived as anything from agents of imperialism, to well-meaning do-gooders capable and willing to suddenly appear with a large bag of cash' (2009). It could have been perceived that as an overseas researcher I came from a position of influence. It was therefore necessary to state from the onset the purpose of the research and how the data collected would be used.

Note 4. This was in a bid to drive out foreigners who they claimed were stealing their jobs and causing crime.

Note 5. These attacks occurred after a community protest against the local municipality, and were accompanied with looting of the foreigners' belongings.

Note 6. Tensions started when an 18-year-old South African alleged robber was shot by a Somali shopkeeper.

Note 7. These countries were regarded as doing comparatively well economically compared to Zimbabwe, Swaziland and Mozambique who were regarded as being considerably more relaxed about the presence of immigrants suggesting that economics plays a central role in triggering xenophobic sentiment.

Note 8. Other factors myths include the perception that migrants are flooding into the country, they steal women, increase crime and spread diseases to mention a few. These factors are not mutually exclusive.

Note 9. Telephone interview on 7 September 2008.

Note 10. Although local South African shopkeepers can purchase goods in bulk, they have to sell their goods at prices set by the local Hawker Associations who determine the minimum price of products. Somalis are not members of local Hawker Associations and therefore to offer more competitive prices

Note 11. The informal sector refers to labour activities that fall outside the formal economy and which are mostly not regulated by government.

Note 12. Ahmed Dawlo is one of the founding members of the Somali Association of South Africa. He is currently the National Director as well as a businessman. Interviewed 6 September 2007 in Highfields Johannesburg.

Note 13. SulegaDahir, a Somali Social Worker working with the Somali Association of South Africa. Interviewed on 31 August 2007 at the Johannesburg Muslim Charity Organisation based in Mayfair, Johannesburg.

Note 14. He is the founder and currently the Coordinator of the Coordinating Body for Refugee Communities. Interviewed 20 August 2007 at the offices of CBRC in Braamfontien Johannesburg.

\section{(cc) $E_{\text {Y }}$}

This work is licensed under a Creative Commons Attribution 3.0 License. 